\title{
Natural Science : Journal of Science and Technology
}

\section{DAFTAR ISI}

1 Kelimpahan Mikroorganisme Tanah Pada Sisntem Perkebunan Kakao (Theobroma cacao L.) Semi Intensif Dan Non Intensif

(Fahrunnisa Yunus dkk)

2 Karakteristik Sarang Tarsius Wallacei Di Lebanu, Sigi, Sulawesi Tengah (Alferi dkk)

3 Uji Daya Hambat Dan Skrining Fitokimia Ekstrak Daun Macaranga tanarius (L.) Mull. Arg Sebagai Antibakteri Salmonella typhi

(Musdalifah dkk)

4 Uji Efektivitas Ekstrak Daun Kirinyuh Chromolaena Odorata (L.) R. M. King Dan H. Rob) Sebagai Herbisida Alami Terhadap Perkecambahan Biji Kacang Hijau (Vigna Radiata (L.) R.Wilczek) Dan Biji Karuilei (Mimosa Invisa Mart. ex Colla)

(Dian Frastika)

5 Keanekaragaman Suku Asteraceae Di Sekitar Danau Kalimpa'a Kawasan Taman Nasional Lore Lindu (Megawati dkk)

6 Laporan Pertama Udang Air Tawar Macrobrachium Scabriculum (Heller, 1862) Dari Batusuya, Donggala, Sulawesi, Indonesia (Diky Dwiyanto)

7 Inventarisasi Jenis-Jenis Nyamuk Di Desa Alindau, Donggala,Sulawesi Tengah

(Moh. Sabir dkk)

8 Purifikasi dan Karakterisasi Silika $\left(\mathrm{SiO}_{2}\right)$ Berbasis Pasir Kuarsa dari Desa Pasir Putih Kecamatan Pamona Selatan Kabupaten Poso

(Indah Ukhtiyani dkk)

9 Pembuatan dan Pengujian Sifat Mekanik Plastik Biodegradable Berbasis Tepung Biji Durian

(Dewi Arini dkk)

10 Kelimpahan Relatif dan Preferensi Habitat pada Kepiting Mangrove (Uca spp.) di Kabonga Kecil, Donggala, Sulawesi Tengah

(Donny Aprilyanto)

11 Identifikasi Lapisan Lapuk Bawah Permukaan Menggunakan Seismik Refraksi di Desa Lengkeka Kecamatan Lore Barat Kabupaten Poso (Vicho Yugho Artono dkk) 
12 Pola Penyebaran Burung di Kawasan Taman Wisata Alam Wera, Sigi, Sulawesi Tengah, Indonesia

(Sultika dkk)

13 Penerapan Autoregressive Distributed Lag ARDL Dalam Memodelkan Pengaruh Indeks Harga Konsumen (IHK) Kelompok Bahan Makanan Dan Kelompok Makanan Jadi Terhadap Inflasi di Kota Palu

(Dewi Yuliastuti Tulak)

14 Dye Sensitized Sol ar Cell Nanokristal $\mathrm{TiO}_{2}$ Menggunakan Ekstrak Antosianin Melastoma malabathricum L

(Satrio Amrullah dkk) 